연구논문

\title{
Dielectric Properites of Iron Sulfide in Coal by Microwave Irradiation
}

\author{
Byoung-Gon Kim ${ }^{1)}$, Chong-Lyuck Park ${ }^{2) *}$ and Jae-Ryeong Lee ${ }^{3)}$ \\ 마이크로웨이브를 이용한 석탄 철황화물들의 유전특성 조사 \\ 김병곤 · 박종력* · 이재령
}

\begin{abstract}
요 약 : 본 연구에서는 마이크로웨이브 조사에 의한 철황화물(황철석, 자황철석, 단유철석)의 유전특성과 상전 이 거동에 대하여 조사하였다. 황철석의 상대자기손실계수는 $915 \mathrm{MHz}$ 와 $2.45 \mathrm{GHz}$ 모두에서 $0.2 \sim 0.4$ 로 나타났 으며, 이것은 황철석은 강자성체 물질이 아님을 나타냈다. 또한 황철석의 상대자기상수는 유전율의 변화를 나타 내는 전기전도도가 증가함에 따라 감소하는 경향을 보였다. 자황철석은 $200^{\circ} \mathrm{C}$ 이하에서 높은 유전상수와 손실계 수를 갖는 것으로 조사되었으며, 이것은 자황철석의 마이크로웨이브 흡수율이 높은 물질임을 보여주는 결과이 다. 단유철석의 유전율과 손실계수의 온도 및 주파수 의존성을 조사한 결과, 마이크로웨이브 조사에 의해 효율적 으로 가열되는 것을 알 수 있었다.
\end{abstract}

주요어 : 석탄탈황, 마이크로웨이브, 유전특성, 철황화물, 상전이

\begin{abstract}
This study focuss on a dielectric and transformation properties of iron sulfide including pyrite, pyrrhotite, and troilite by microwave heation. The relative magnetic loss factors of pyrite at both $915 \mathrm{MHz}$ and $2.45 \mathrm{GHz}$ are between 0.2 and 0.4 . This shows that pyrite is not a strong magnetic substance. Also, the decrease of the relative magnetic constant of pyrite is caused by the increase of electrical conductivity of sample, as indicated by the variation of permittivity. The large dielectric constant and loss factor of pyrrhotite at temperatures below $200^{\circ} \mathrm{C}$ suggest that this phase has good microwave absorption capability at microwave frequency. The dielectric constant and loss factor of troilite are found to be highly temperature and frequency dependent.
\end{abstract}

Key words : Coal Desulfurization, Microwave, Dielectric Property, Iron Sulfide, Phase transition

\section{Introduction}

The coal industry is facing a challenge to be replaced by clean energy like nuclear energy, with depletion of high rank-coal and social awareness that coal combustion is the main culprit of global warming around the world. Especially, sulfur in coal has been identified as hazardous substance due to oxidation in coal combustion. Therefore, it needs to be removed before coal utilization. Most of inorganic sulfur occurs in coal with pyritic and sulfate forms, which

2013년 10월 4일 접수, 2013년 12월 5일 심사완료

2013년 12월 12일 게재확정

1) 한국지질자원연구원 광물자원연구본부

2) 포스코 기술연구원 원료연구그룹

3) 강원대학교 공과대학 에너지자원공학과

*Corresponding Author(박종력)

E-mail; clpark@posco.com

Address; Technical Research Laboratories 1, Geodong-dong, Nam-gu, Pohang, Gyeongbuk 790-300, Korea is hard to be reduced through conventional dry separation methods without selective flocculation using polyxanthate and froth flotation (Attia et al., 1988; Lee et al., 2008).

However, researchers have found that sulfur in pyrrhotite $\left(\mathrm{Fe}_{1-\mathrm{x}} \mathrm{S}\right)$ could be easily removed by magnetic separation due to its high magnetic susceptibility. For example, monoclinic pyrrhotite exhibits much higher apparent magnetic susceptibility than pyrite $\left(22 \times 10^{6}\right.$ and $0.3 \times 10^{6}$ cgs emu per gram, respectively) (Ergun and Bean, 1968). The conversion of pyrite to pyrrhotite is thus expected to obtain an apparent increase of magnetic susceptibility, leading to higher efficiency of magnetic separation of sulfur from coal. Ergun and Bean (1968) found that conversion of only $0.5 \%$ of pyrite $\left(\mathrm{FeS}_{2}\right)$ to pyrrhotite would be sufficient to produce an apparent magnetic susceptibility of 10 or more (Ergun and Bean, 1968). They also proposed that high- frequency heating of coal might achieve selective absorption by pyrite and partial conversion 
to pyrrhotite. Nelson et al. (1981) noticed that the dielectric loss factor of a dense pyrite bearing portion separated from coal with high sulfur content increases with microwave frequency (Nelson et al., 1981). Bluhm et al. (1986) investigated the variation of apparent magnetic susceptibility during the microwave heating. The results indicated that the susceptibility can be increased by microwave heating. Fanslow et al. (1980) found that pyrite in coal could be heated nine times faster than "clean coal" at $2.45 \mathrm{GHz}$. It indicated that the selective heating of pyrite and conversion of pyrite to pyrrhotite using microwave are possible to achieve. Weng (1993) and Weng et al. (1990) investigated the effect of heating time at specified power on the inorganic desulfurization efficiency. It was discovered that $91 \%$ inorganic sulfur could be removed by magnetic separation at $0.6 \mathrm{~T}$ following microwave heating with $1.5 \mathrm{~kW}$ at $2.45 \mathrm{GHz}$ for $60 \mathrm{~s}$. Uslu and Atalay (2004) studied the microwave heating of lignite for enhanced magnetic removal of pyrite. They showed that the separation efficiency was significantly increased with addition of $5 \%$ magnetite, which is an excellent microwave absorber. Furthermore, $55.11 \%$ pyritic sulfur in coal could be reduced by magnetic separation at magnetic field of $2 \mathrm{~T}$ following microwave heating.

The above studies demonstrated that coal desulfurization assisted by microwave heating provides a promising solution to the problem of sulfur removal of coal. The efficiency of desulfurization relies on several parameters such as microwave frequency, power, sample mass, pyrite content, coupling agent and heating time. However, it is also noticed that all above researchers have not considered the variations of dielectric and magnetic properties of coal components during microwave heating. Since microwave heating is highly dependent on these properties, it is extremely important to determine the corresponding parameters for major sulfur minerals and other related phases in coal, especially pyrite, pyrrhotite and troilite.

\section{Experimental}

\section{Raw Materials}

The identification of phase in a sample was performed via X-Ray Diffraction (XRD). XRD patterns for the samples were obtained using a conventional Scintag XDS-2000 powder X-ray diffractometer with a graphite monochromator and $\mathrm{Cu} \mathrm{Ka}$ radiation.

Pyrite $\left(\mathrm{FeS}_{2}\right.$, Zacatecas, Mexico) samples were obtained from Ward's Natural Science Establishment, Inc. USA. The composition was confirmed using X-ray Diffraction, as shown in Fig. 1(a). It is seen that there is no observable impurity in the sample.

Pyrrhotite $\left(\mathrm{Fe}_{1-\mathrm{x}} \mathrm{S}, \mathrm{x}=0.125\right.$, Chihuahua, Mexico) sample was obtained from OBG Gems \& Minerals, Co. USA. The natural pyrrhotite sample was crushed before use and the composition was confirmed using X-ray diffraction (Fig. 1(b)). Furthermore, to evaluate the thermal stability of pyrrhotite, in situ high temperature X-ray diffraction (HT-XRD) was carried out using a PANalytical X'Pert PRO X-ray diffractometer with $\mathrm{Cu} \mathrm{Ka}$ radiation.

Troilite sample (FeS, 99.9\% purity) was purchased from Sigma Aldrich, Corp., USA The sample composition was identified using XRD (Fig. 1(c)).

All samples were crushed under 200 mesh before use.

\section{Dielectric Property Measurement}

Dependent upon the frequency and temperature range, the dielectric response of a substance is commonly presented as permittivity $(\varepsilon)$, which can be given by (Peng et al., 2010)

$$
\varepsilon=\varepsilon_{0} \varepsilon_{r}=\varepsilon_{0}\left(\varepsilon^{\prime}{ }_{r}-j \varepsilon^{\prime \prime}{ }_{r}\right)
$$

where $\varepsilon_{r}$ is the complex relative permittivity, and $j$ is the imaginary unit $\left(j^{2}=-1\right)$. Since the values of permittivity for most materials are quite small, the complex relative permittivity is usually used instead to describe the dielectric response. As indicated by Eq. (1), the complex relative permittivity is comprised of two components: the real part $\left(\varepsilon_{r}{ }^{\prime}, \mathrm{F} / \mathrm{m}\right)$ and imaginary part $\left(\varepsilon_{r}{ }^{\prime \prime}, \mathrm{F} / \mathrm{m}\right)$. The real part is generally known as relative dielectric constant, which is a measure of the ability of the dielectrics to store electrical energy. The imaginary part is also called relative dielectric loss factor, which represents the loss of electrical energy in dielectrics, as mentioned before. For common non- magnetic inorganic substance, $\varepsilon_{r}$ " determines the heating rate under microwave irradiation.

In this study, to determine the dielectric properties $\left(\varepsilon_{r}{ }^{\prime}\right.$ and $\left.\varepsilon_{r}{ }^{\prime \prime}\right)$ of the inorganic components of coal, the cavity perturbation technique was employed for the measurements 
at $915 \mathrm{MHz}$ and 2,450 MHz, the two frequencies available for industrial and domestic applications (Peng et al., 2011; Pickles et al., 2005). This method measures the differences (frequency shift and change of quality factors) in the

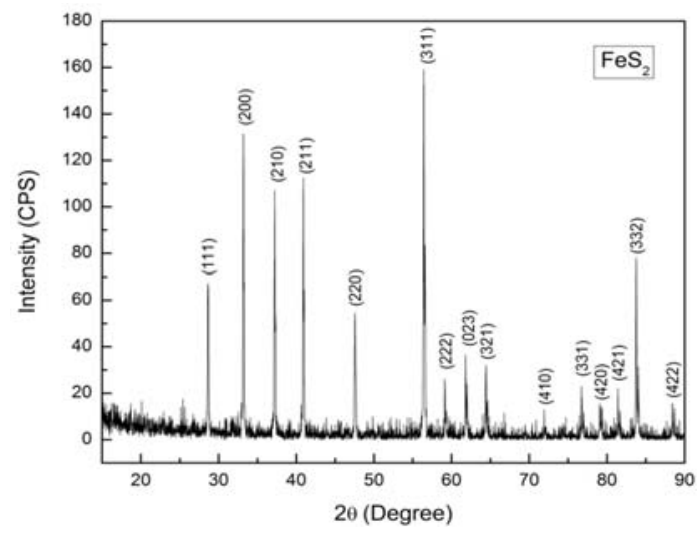

(a) Pyrite

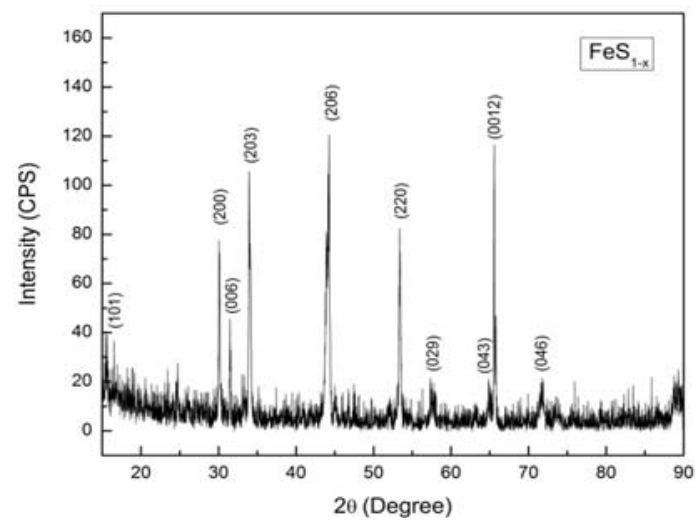

(b) Pyrrhotite

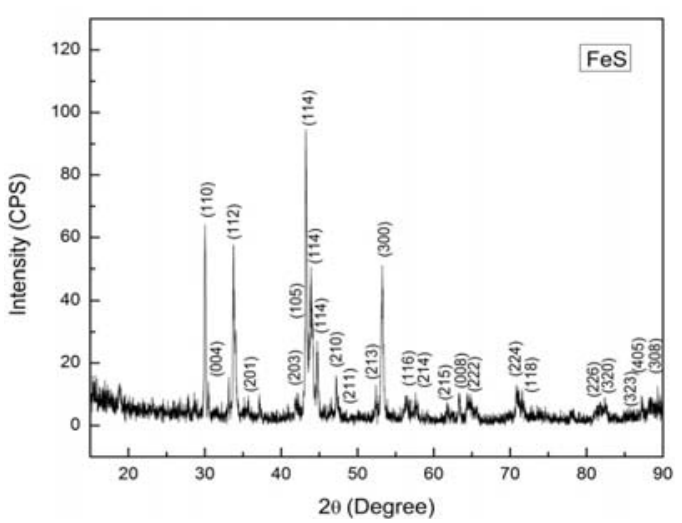

(c) Troilite

Fig. 1. XRD patterns of raw materials. microwave cavity response between a cavity with an empty sample-holder and the same cavity with a sampleholder plus the sample. These differences are then used to calculate the permittivity.

As illustrated in Fig. 2, the major components of the measurement system are a resistive heating furnace and a cylindrical $\mathrm{TM}_{0 \mathrm{n} 0}$ resonant mode cavity $(\varnothing 580 \mathrm{~mm} \times 50$ $\mathrm{mm}$ ). To measure the permittivity at specific temperature, the top section of the holder containing sample was raised into the furnace and held at least $5 \mathrm{~min}$ to ensure that the sample achieves the equilibrium furnace temperature. Then the holder with hot sample was quickly $(<1.5 \mathrm{~s}$ for each frequency) lowered into the central, maximum electric field region of the thick-walled, well-cooled copper $\mathrm{TM}_{0 \mathrm{n} 0}$ cavity, where the frequency shift $\Delta f$ and quality factor $Q$ due to the sample insertion were recorded in a Hewlett Packard 8753B vector network analyzer.

With the data of the frequency shift $\Delta f$ and quality factor $Q$, the electric susceptibility $\left(\chi_{e}=\chi_{e}{ }^{\prime}-j \chi_{e}{ }^{\prime \prime}\right)$ was calculated through the following equation (Peng et al., 2010):

$$
\frac{\Delta f}{f_{e}}+j\left(\frac{1}{2 Q_{L, S}}-\frac{1}{2 Q_{L, E}}\right)=\frac{-\chi_{e}}{1+F_{s h} \chi_{e}}\left(\frac{V_{s}}{V_{c}}\right) A
$$

where $f_{e}$ is the specific cavity mode frequency $(915 \mathrm{MHz}$ or $2450 \mathrm{MHz}), Q_{L, E}$ is the loaded cavity quality factor with the empty holder, $\Delta f$ is the frequency shift produced by the

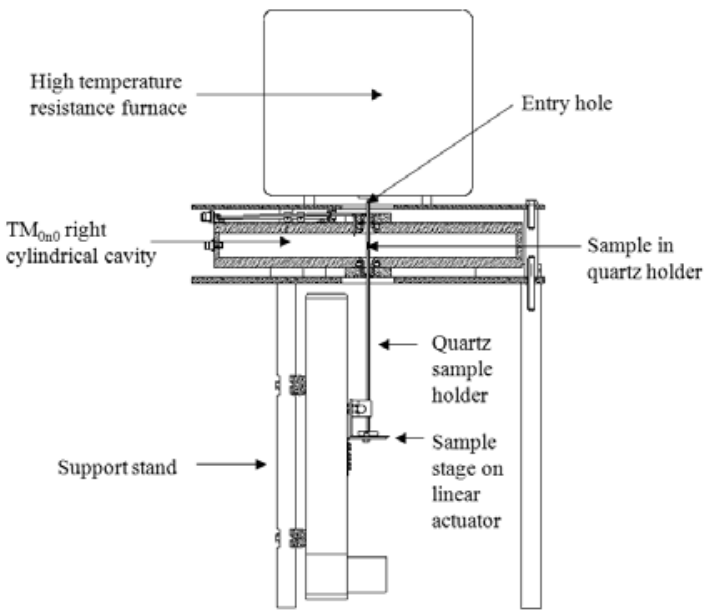

Fig. 2. Schematic diagram of the dielectric and magnetic characterization system (Peng et al., 2011). 
sample, $Q_{L, S}$ is the loaded cavity $Q$ with the holder and sample, $F_{s h}$ is a real number dependent only on the sample shape, $V_{s}$ and $V_{c}$ are the respective sample and cavity volumes, $A$ is a real calibration constant dependent only on the shape of the electric fields in the absence of the sample. After the susceptibility was determined, the permittivity parameters include relative dielectric constant $\left(\varepsilon_{r}\right)$ and dielectric loss factor $\left(\varepsilon_{r}{ }^{\prime \prime}\right)$ were calculated.

\section{Magnetic Property Measurement}

Dependent upon the frequency and temperature range, the magnetic response of a substance in microwave heating can be presented as permeability $(\mu)$, which is given by (Peng et al., 2010):

$$
\mu=\mu_{0} \mu_{r}=\mu_{0}\left(\mu_{r}^{\prime}-j \mu_{r}^{\prime \prime}\right)
$$

where $\mu_{r}$ is the complex relative permeability. Since the values of permeability for most materials are quite small, the complex relative permeability is usually used instead to describe the magnetic response. As indicated by Eq. (3), the complex relative permeability is comprised of two components: the real part $\left(\mu_{r}{ }^{\prime}\right)$ and imaginary part $\left(\mu_{r}{ }^{\prime \prime}\right)$. The real part is generally known as relative magnetic constant, which is a measure of the ability of the magnetic dielectrics to store magnetic energy. The imaginary part is also called relative magnetic loss factor, which represents the loss of magnetic energy in the dielectrics. For common magnetic inorganic substance, $\mu_{r}$ "significantly influences the heating rate under microwave irradiation.

In order to evaluate the magnetic loss in microwave heating of coals, the permeability measurements for some inorganic phases in the coal samples were performed.

The complex permeability was measured using a ridgeloaded-WR284 waveguide-based resonant cavity which produces a region of maximum magnetic field strength at the shorted end of the waveguide. The sample was moved rapidly into this maximum field, and again the frequency shift and change in loaded $Q$ are measured. The complex permeability is calculated using a formula identical in form to Eq. (2), but with the appropriate frequency and $Q$ and shape factors and calibration constants for the magnetic cavity.

The permeability measurements are, in practice, less accurate than permittivity measurements because large corrections have to be made for the frequency and $Q$ shift in the magnetic cavity that are caused by the small, but significant, electric field that exists in the high magnetic field region. Since the complex dielectric constant is almost always much larger (typically 10 times) than the complex permeability, the small electric field causes frequency shifts and $Q$ changes that must be taken into account. Thus the magnetic measurements require subtractions that depend upon reliable values at each temperature of the complex permittivity. Only after these corrections have been made, can the complex magnetic susceptibility $\chi_{m}$, be determined by using the following equation:

$$
\frac{\Delta f}{f_{m}}+j\left(\frac{1}{2 Q_{L, S}}-\frac{1}{2 Q_{L, E}}\right)=\frac{-\chi_{m}}{1+F_{s h} \chi_{m}}\left(\frac{V_{s}}{V_{c}}\right) A
$$

where $f_{m}$ is the cavity mode frequency in permeability test, and the $\Delta f$ and $Q$ are only from the magnetic field induced contribution. Even after these corrections, other problems exist in the interpretation of the apparent measured magnetic susceptibility. If the sample has a moderately large highfrequency electrical conductivity (which is determined by the permittivity measurements), the time-varying microwave magnetic field can induce electrical fields in the sample that produce azimuthal induced currents in the sample, completely analogous to low frequency induction heating. This represents another mechanism of power loss in the sample, and produces power loss and a reduction in $Q$. However, these losses are mainly due to the electrical conductivity of the sample, which is part of the imaginary permittivity. These "induced electric field" losses are not significant in the permittivity measurements because of the very low magnetic field in the central region of the $\mathrm{TM}_{0 \mathrm{n} 0}$ cavity, relative to the electric field.

Another problem occurs if the sample conductivity is very high, as with an almost metallic sample. If the conductivity is such that the skin depth is small relative to the diameter of the sample, this implies that the induced currents produce a "bucking" magnetic field in the sample interior that exactly counters the cavity magnetic field. In this way, all magnetic fields are excluded from the interior of the sample. This is the typical Lenz Law situation, and implies an "apparent" magnetic susceptibility, $\chi_{m}=-1$, or a value $m_{r}=0$ if interpreted incorrectly using Eq. (4). These problems can only be avoided by a detailed 
knowledge of the physical and solid state properties of the sample at all temperatures.

During each permittivity and permeability measurement, the sample powders were first uniaxially pressed at about $200 \mathrm{MPa}$ in a die lined with tungsten carbide to form 3 pellets with a diameter of about $3.5 \mathrm{~mm}$ and a total, stacked length (height) of about $12 \mathrm{~mm}$. They were subsequently step-heated to the designated temperatures, all done in $0.01 \mathrm{l} / \mathrm{min}$ flowing UHP argon. The whole measurement sequence was pre-programmed and temperature calibration in the furnace, movement of the linear actuator (Fig. 2), and network analyzer analysis were all controlled by a PC running Labview control software.

\section{Results and Discussion}

Microwaves are electromagnetic waves having frequency range of which is from 0.3 to $300 \mathrm{GHz}$ (corresponding to wavelengths, $\lambda$, from $1 \mathrm{~mm}$ to $1 \mathrm{~m}$ ). Microwave energy dissipates instantaneously throughout the volume of the material and heats it directly, resulting in much higher heating efficiency than conventional heating methods (Hotta et al., 2011).

Quantitatively, microwave absorption $\left(Q, \mathrm{~W} / \mathrm{m}^{3}\right)$ by material can be described by the following equation:

$$
Q=\frac{1}{2} \omega \varepsilon_{0} \varepsilon_{r}^{\prime \prime}|E|^{2}+\frac{1}{2} \omega \mu_{0} \mu_{r}^{\prime \prime}|H|^{2}
$$

where $\omega$ is the microwave angular frequency, $\varepsilon_{0}$ is the permittivity of free space $\left(8.854 \times 10^{-12} \mathrm{~F} / \mathrm{m}\right), \mathcal{E}_{r}{ }^{\prime \prime}$ is the imaginary part of complex relative permittivity (also known as relative dielectric loss factor) of material, $|E|$ is the microwave electric field amplitude in material, $\mu_{0}$ is the permeability of free space $\left(4 \mathrm{p} \times 10^{-7} \mathrm{H} / \mathrm{m}\right), \mu_{r}{ }^{\prime \prime}$ is the imaginary part of complex relative permeability (also known as relative magnetic loss factor) of material, and $|H|$ is the microwave magnetic field amplitude in material.

As indicated by Eq. (5), microwave heating depends on the dielectric (permittivity) and magnetic (permeability) properties of material. For microwave heating of coal, most organic fraction of coal presents low dielectric loss and is essentially transparent to microwaves at room temperature. Inorganic components of coal such as water and pyrite, however, have been identified as good microwave absorbers (Fanslow et al., 1980). Consequently, to seek the optimal conditions regarding the microwave coal desulfurization and drying, it is essential to characterize the dielectric and magnetic properties of main inorganic components of coal.

During the desulfurization process, the following reactions may occur:

$$
\mathrm{FeS}_{2} \rightarrow \mathrm{Fe}_{1-X} \mathrm{~S} \rightarrow \mathrm{FeS} \rightarrow \mathrm{Fe}_{3} \mathrm{O}_{4} \rightarrow \mathrm{Fe}_{2} \mathrm{O}_{3}
$$

The first step is known as decomposition reaction of pyrite $\left(\mathrm{FeS}_{2}\right)$, leading to formation of pyrrhotite $\left(\mathrm{Fe}_{1-\mathrm{x}} \mathrm{S}\right)$. The pyrrhotite may further decompose to troilite ( $\mathrm{FeS}$, less stable) and then oxidize to magnetite $\left(\mathrm{Fe}_{3} \mathrm{O}_{4}\right)$ and hematite $\left(\mathrm{Fe}_{2} \mathrm{O}_{3}\right)$ in air. Due to these phase transformations, the dielectric and magnetic properties of these phases need to be determined.

\section{Pyrite $\left(\mathrm{FeS}_{2}\right)$}

Fig. 3 presents the results of thermogravimetric analyses of pyrite sample, which were performed using a TA Instruments Q50 Thermogravimetric Analyzer with heating rate of 5 degree/min in a stream of nitrogen at a flow rate of 100 $\mathrm{ml} / \mathrm{min}$. The TG/DTG curves in the figure indicate the sample still consists of pyrite phase at $500^{\circ} \mathrm{C}$. Pyrite decomposition does not start below $500^{\circ} \mathrm{C}$ and higher temperature leads to apparent weight loss between 500 and $650^{\circ} \mathrm{C}$. This is caused by the transformation of pyrite to pyrrhotite, as shown by the following reaction (Toulmin and Barton, 1964):

$$
(1-X) \mathrm{FeS}_{2} \rightarrow \mathrm{Fe}_{1-X} \mathrm{~S}_{+}(0.5-X) \mathrm{S}_{2}(\mathrm{~g})
$$

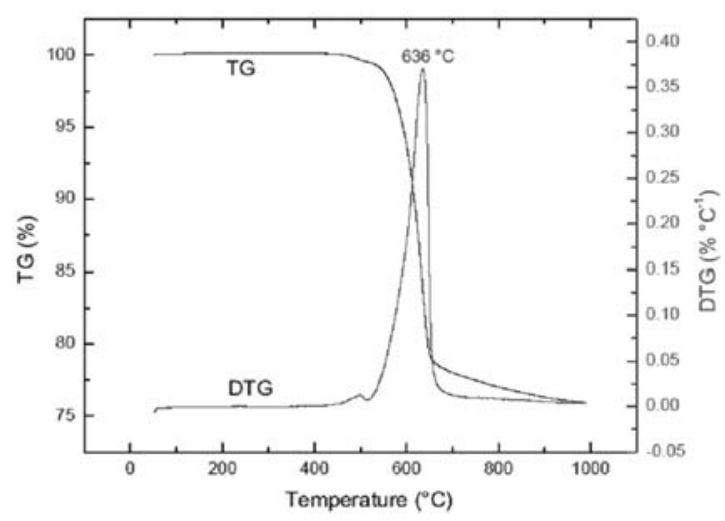

Fig. 3. TG and DTG curves of $\mathrm{FeS}_{2}$. 
This transformation is found to be an endothermic reaction. It suggests that it is necessary to heat pyrite to at least $500^{\circ} \mathrm{C}$ to fully transform pyrite to magnetic pyrrhotite. This result agrees with the phenomenon observed by Bhargava et al. in 2009.

Fig. 4 shows the permittivity of pyrite at frequency of $915 \mathrm{MHz}$. The high dielectric loss factor at room temperature indicates that pyrite can be heated effectively using microwaves. The relative dielectric constant and relative dielectric loss factor slightly increase with temperature up to about $450^{\circ} \mathrm{C}$. Then both parameters show peaks locating at around $500^{\circ} \mathrm{C}$. This is related to the phase transformation of pyrite. The rapid drop of permittivity of pyrite is probably ascribed to the formation of pyrrhotite. Continuous heating to $750^{\circ} \mathrm{C}$ results in dramatic increase of dielectric constant due to the thermal excitation of pyrite

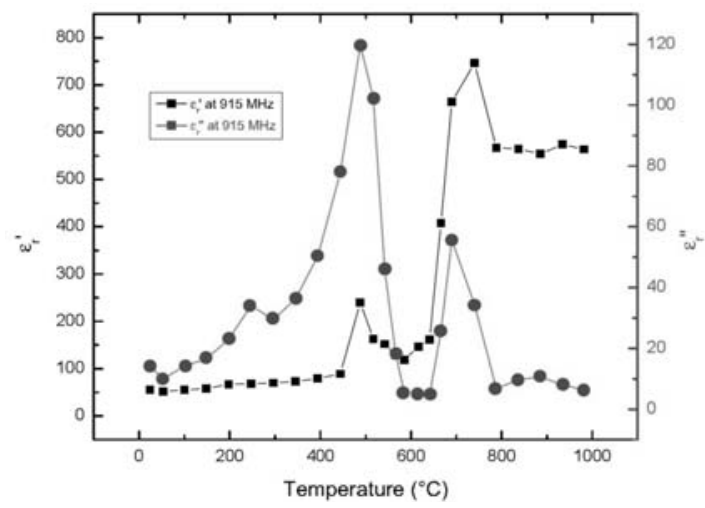

Fig. 4. Permittivity of $\mathrm{FeS} 2$ at $915 \mathrm{MHz}$ : $\mathcal{E}_{r}{ }^{\prime}$-relative dielectric constant and $\varepsilon_{r}{ }^{\prime \prime}$-relative dielectric loss factor.

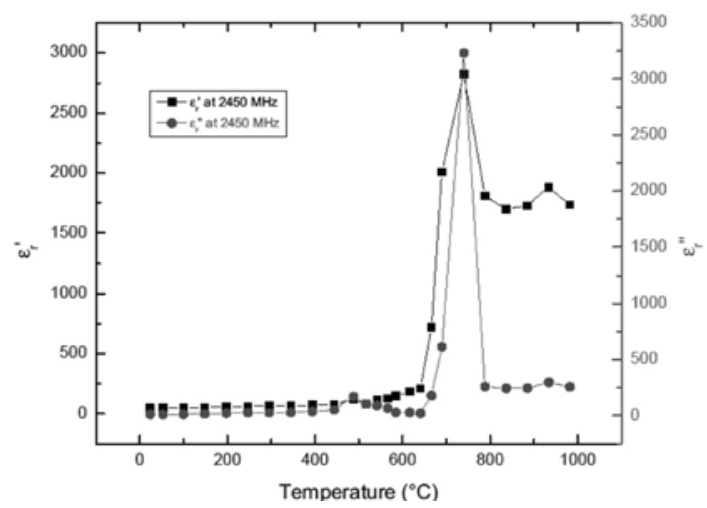

Fig. 5. Permittivity of $\mathrm{FeS}_{2}$ at $2450 \mathrm{MHz}$ : $\mathcal{E}_{r}^{\prime}$-relative dielectric constant and $\varepsilon_{r}{ }^{\prime \prime}$-relative dielectric loss factor. atoms. The relatively constant permittivity above $800^{\circ} \mathrm{C}$ is assumed to be caused by the sintering effect.

Fig. 5 shows the temperature dependency of permittivity of $\mathrm{FeS}_{2}$ at $2450 \mathrm{MHz}$. The most significant feature in the figure is that at $2450 \mathrm{MHz}$, pyrite samples exhibit sharper increases of the dielectric constant and loss factor when the temperature is increased to about $700^{\circ} \mathrm{C}$. This difference stems from the stronger friction between sample atoms at higher frequency.

As can be seen from Fig. 4 and 5, pyrite presents large dielectric losses at the given microwave frequencies. This observation is in agreement with the experimental finding in which pyrite in coal could be heated nine times faster than "clean coal" at $2.45 \mathrm{GHz}$ (Fanslow et al., 1980).

The variations of permeability of $\mathrm{FeS}_{2}$ with temperature below $500^{\circ} \mathrm{C}$ at 915 and $2450 \mathrm{MHz}$ are shown in Fig. 6 and

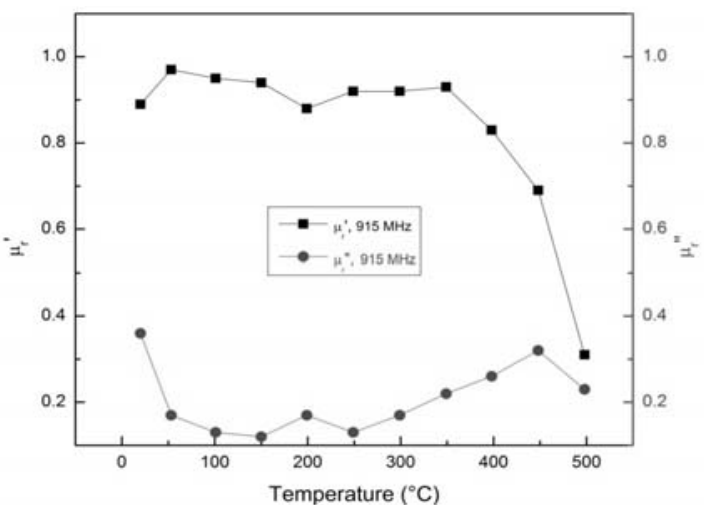

Fig. 6. Permeability of $\mathrm{FeS}_{2}$ at $915 \mathrm{MHz}$ : $\mu_{r}^{\prime}$-relative magnetic constant and $\mu_{r}{ }^{\prime \prime}$-relative magnetic loss factor.

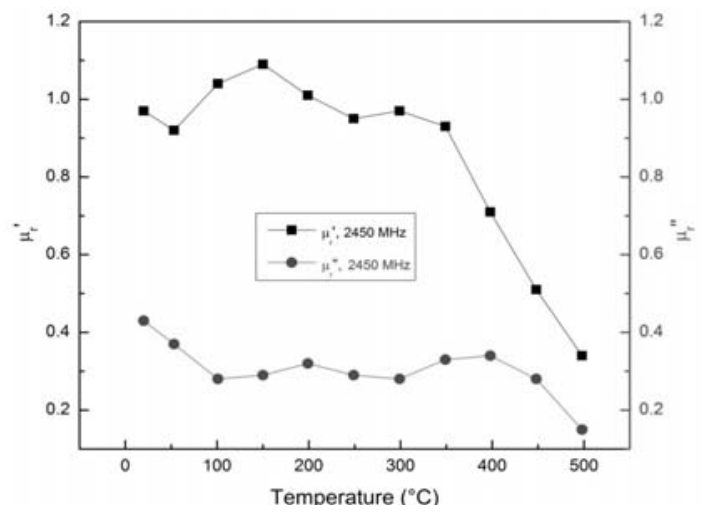

Fig. 7. Permeability of $\mathrm{FeS}_{2}$ at $2450 \mathrm{MHz}: \mu_{r}^{\prime}$-relative magnetic constant and $\mu_{r}{ }^{\prime \prime}$-relative magnetic loss factor. 
Fig. 7, respectively. It is presented that the relative magnetic loss factors of $\mathrm{FeS}_{2}$ at both frequencies are between 0.2 and 0.4 in this temperature range. This suggests that although pyrite is not a strong magnetic substance, it still contributes to the magnetic loss in microwave heating of the coals. In other words, compared to organic phases of coals, pyrite presents better microwave absorption property. Since $\mathrm{FeS}_{2}$ has high dielectric loss factor even at room temperature, as discussed above, it can be considered as a microwave absorber in microwave heating of coal due to its dielectric loss and magnetic loss. Also, note that the decrease of the relative magnetic constant is caused by the increase of electrical conductivity of sample, as indicated by the variation of permittivity with temperature before.

\section{Pyrnhotite $\left(\mathrm{Fe}_{1-\mathrm{x}} \mathrm{S}\right)$}

Fig. 8 shows the HT-XRD patterns of pyrrhotite sample at temperature ranging from 25 to $1000^{\circ} \mathrm{C}$. It is identified that no obvious phase transformation was observed below $1000^{\circ} \mathrm{C}$. However, it should be emphasized that the peaks of XRD patterns shift to lower angles and show weak intensity at high temperatures. The shift is believed to be largely a consequence of thermal expansion of lattice planes, followed by increase of the inter-planar distance (d). It can be illustrated by Bragg's law (Liu et al., 2008; Okolo et al., 2004):

$$
d=n \lambda /(2 \sin \theta)
$$

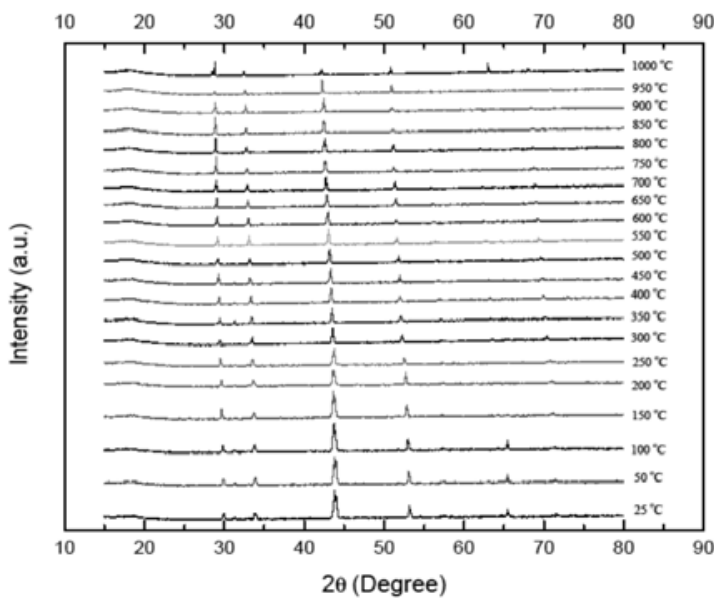

Fig. 8. In situ $\mathrm{HT}-\mathrm{XRD}$ patterns of $\mathrm{Fe}_{1-\mathrm{x}} \mathrm{S}$ analyzed in vacuum. where $n$ is an integer determined by the order given, $\lambda$ is the wavelength, and $\theta$ is the scattering angle. The decrease of peak intensity is caused by the Debye temperature effect on the X-ray diffraction. Since the melting point of pyrrhotite is lower than $1188^{\circ} \mathrm{C}$ (depending on nonstoichiometry), this effect becomes strong at temperature above $800^{\circ} \mathrm{C}$ (Jensen, 1942).

Fig. 9 and 10 present the temperature dependences of permittivity of $\mathrm{Fe}_{1-\mathrm{x}} \mathrm{S}$ at $915 \mathrm{MHz}$ and $2450 \mathrm{MHz}$, respectively. The large dielectric constant and loss factor of $\mathrm{Fe}_{1-\mathrm{x}} \mathrm{S}$ at temperatures below $200^{\circ} \mathrm{C}$ suggest that this phase has good microwave absorption capability at microwave frequency. This result is in agreement with the experimental observation.

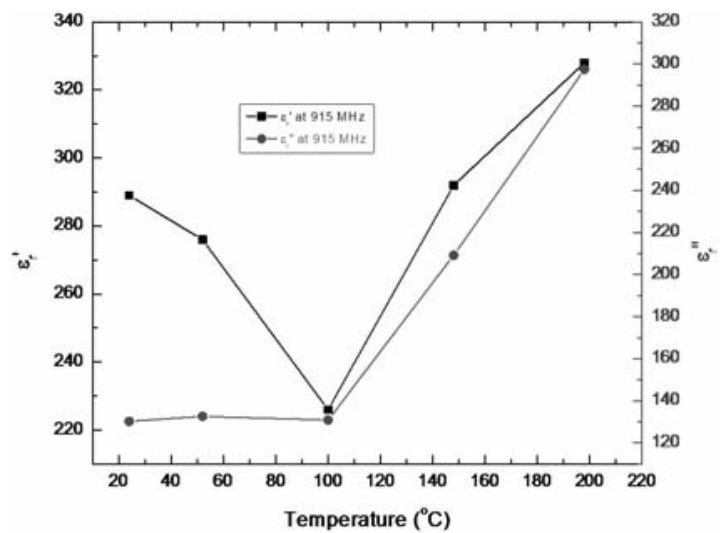

Fig. 9. Permittivity of $\mathrm{Fe}_{1-\mathrm{x}} \mathrm{S}$ at $915 \mathrm{MHz}$ : $\mathcal{E}_{r}^{\prime}$-relative dielectric constant and $\mathcal{E}_{r}{ }^{\prime \prime}$-relative dielectric loss factor.

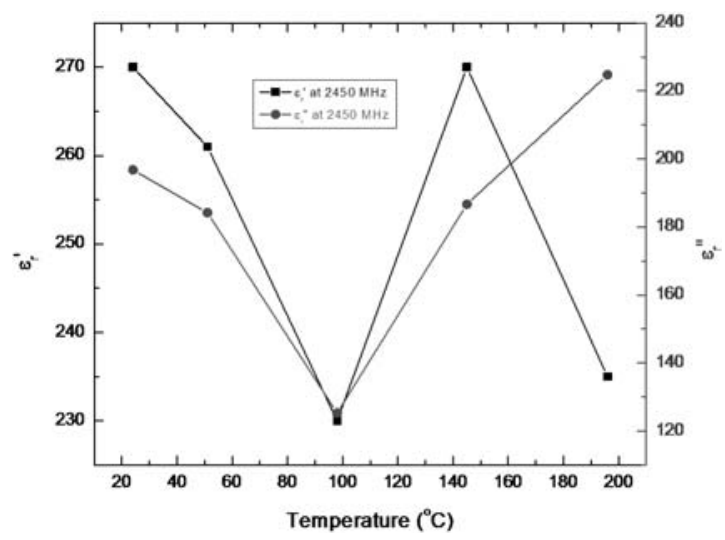

Fig. 10. Permittivity of $\mathrm{Fe}_{1-\mathrm{x}} \mathrm{S}$ at $2450 \mathrm{MHz}: \mathcal{E}_{r}^{\prime}$-relative dielectric constant and $\varepsilon_{r}{ }^{\prime \prime}$-relative dielectric loss factor. 


\section{Troilite (FeS)}

Fig. 11 shows the HT-XRD patterns of troilite sample. The split peak corresponding to (114) lattice plane in Fig. 2 (c) indicates that the sample may contain little pyrrhotite. This is mainly due to the chemical similarity between these two phases. From the HT-XRD patterns in Fig. 11, it is seen that there is a small phase transformation in the temperature range of 100 to $300^{\circ} \mathrm{C}$. This can be assigned to the conversion of pyrrhotite to FeS. At high temperatures, such as $1000^{\circ} \mathrm{C}$, only pretty weak X-ray diffraction signals could be detected as a consequence of breakdown of crystal structure during the melting of FeS.

To identify the thermal stability of FeS, thermogravimetric analyses of the sample was performed. TG/DTG curves in Fig. 12 indicate that a slight mass loss occurs between 100 and $300^{\circ} \mathrm{C}$. This result is almost coincident with that of HT-XRD. Also, it is found that the sample gradually loses weight above $600^{\circ} \mathrm{C}$. This indicates the thermal instability of iron sulfide at high temperatures although the specific reaction mechanism has not been clarified yet.

Fig. 13 and 14 show the temperature dependences of permittivity of $\mathrm{FeS}$ at $915 \mathrm{MHz}$ and 2,450 $\mathrm{MHz}$, respectively. The dielectric constant and loss factor of FeS are found to be highly temperature and frequency dependent. It is also noticed that the values at $915 \mathrm{MHz}$ vary abruptly between $100^{\circ} \mathrm{C}$ and $300^{\circ} \mathrm{C}$. This is probably due to the phase transformation of iron sulfide, as discussed above. Furthermore, the data in both figures

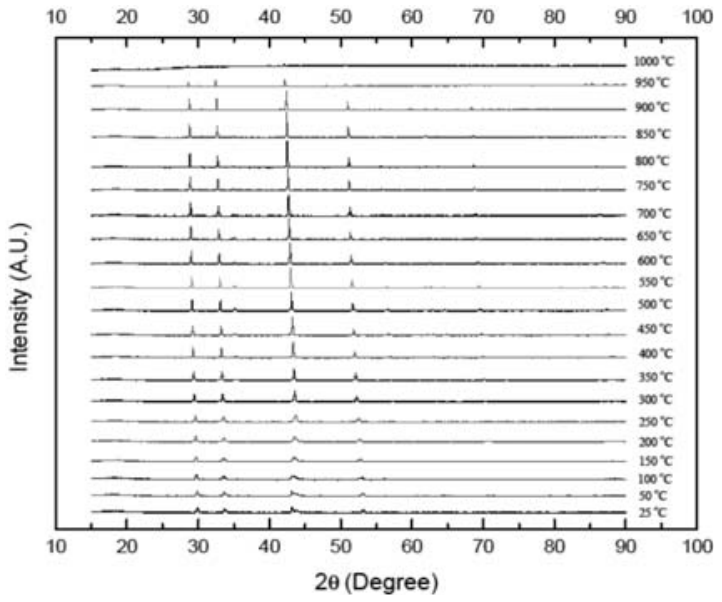

Fig. 11. In situ HT-XRD patterns of FeS sample analyzed in vacuum.

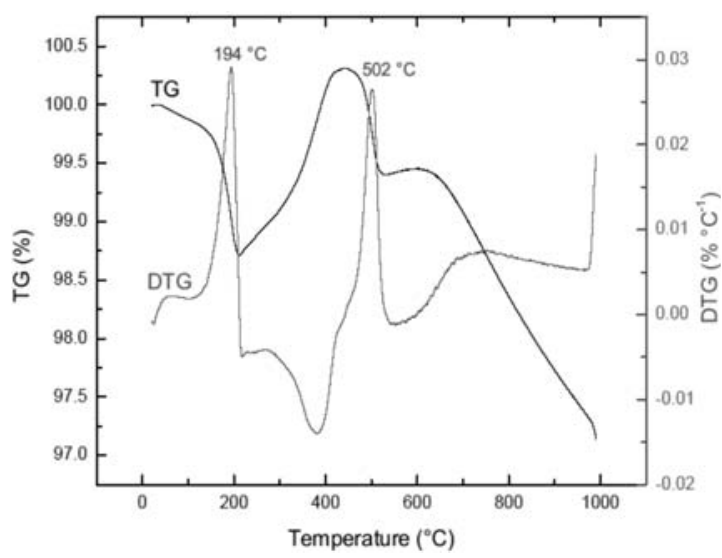

Fig. 12. TG and DTG curves of FeS.

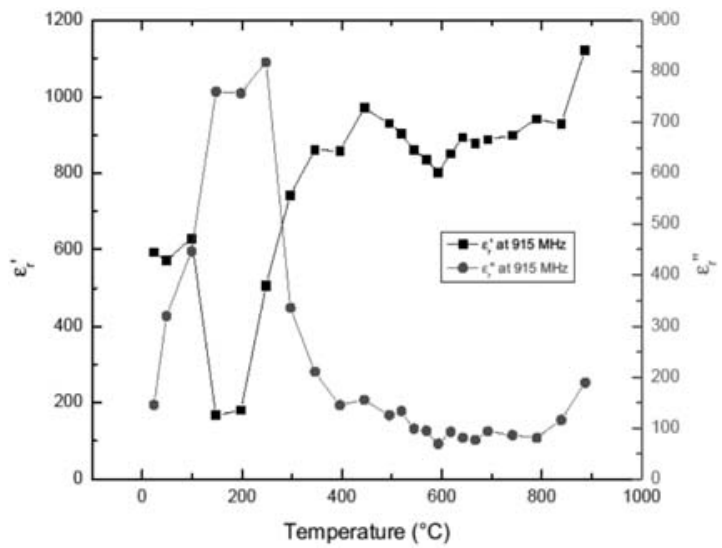

Fig. 13. Permittivity of $\mathrm{FeS}$ at $915 \mathrm{MHz}$ : $\mathcal{E}_{r}^{\prime}$-relative dielectric constant and $\varepsilon_{r}{ }^{\prime \prime}$-relative dielectric loss factor.

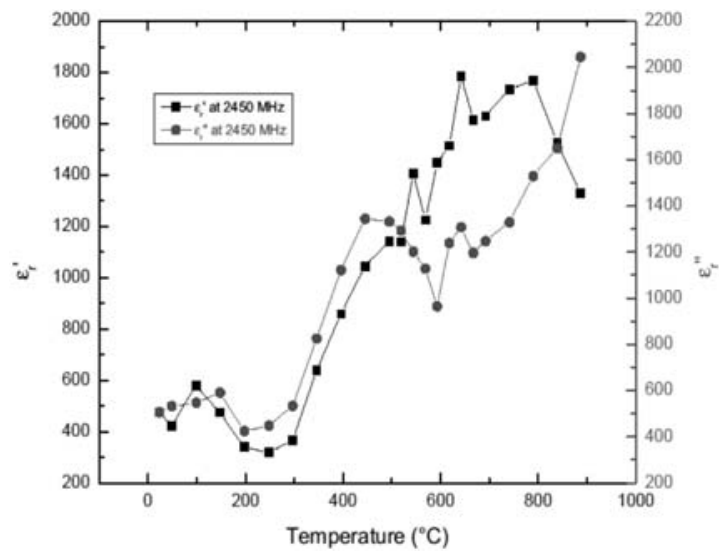

Fig. 14. Permittivity of $\mathrm{FeS}$ at $2450 \mathrm{MHz}$ : $\mathcal{E}_{r}{ }^{\prime}$-relative dielectric constant and $\varepsilon_{r}$ "-relative dielectric loss factor. 
indicates that $\mathrm{FeS}$ exhibits high dielectric loss even at room temperature. It is thus reasonable to assume that troilite can be efficiently heated by microwaves although this phase is extremely rarely encountered in the Earth's crust.

\section{Conclusions}

The microwave heating is a good solution to the problem of iron sulfide minerals removal of coal. However, most of researchers have not considered the variations of dielectric and magnetic properties of coal components during microwave heating. In this study, we focussed on a transformation properties of iron sulfide including pyrite, pyrrhotite, and troilite by microwave heation.

Microwave dielectric measurements suggest that iron sulfides have good microwave absorption capabilities. The magnetic measurements show that pyrite exhibits magnetic loss in microwave heating. Hematite does not present noticeable magnetic response below $1000^{\circ} \mathrm{C}$ and magnetite possesses strong magnetism at room temperature and then gradually loses it with increasing temperature due to "Curie point" effect.

Pyrite decomposes to pyrrhotite or troilite at temperature above $500^{\circ} \mathrm{C}$ in non-oxygen/low pressure atmosphere. Pyrrhotite or troilite in vacuum remain relatively stable in the temperature range of $24-1,000^{\circ} \mathrm{C}$. Oxidation of pyrite produces magnetite and hematite. The formation of magnetite could enhance the efficiency of magnetic separation of sulfur-containing coal. Excessive formation of hematite may cause energy loss and low microwave heating effectiveness.

\section{Acknowledgements}

This research was supported by the Energy and Mineral Resources Engineering Program Grant funded by the Ministry of Knowledge Economy, Korea. Also, the authors would like to thank the Microwave Properties North (MPN) for their support of this research.

\section{References}

Attia, Y.A., Bavarian, F. and Driscoll, K.H., 1988 "Use of Polyxanthate Dispersant for Ultra Pyrite Removal from
High Sulfur Coal by Selective Flocculation," Coal Preparation, Vol. 6, Issue. 1-2, pp. 35-51.

Bhargava, S.K., Garg, A. and Subasinghe, N.D., 2009, "In situ high-temperature phase transformation studies on pyrite," Fuel, Vol. 88, Issue. 6, pp. 988-993.

Bluhm, D.D., Fanslow, G.E. and Nelson, S.O., 1986, "Enhanced Magnetic Separation of Pyrite from Coal after Microwave heating," IEEE Transactions on Magnetics, Vol. 22, Issue. 6, pp. 1887-1890.

Ergun, S. and Bean, E.H., 1968, "Magnetic Separation of Pyrities from Coals," Bureau of Mines Report of Investigations, No. 7181, p. 9.

Fanslow, G.E., Bluhm, D.D. and Nelson, S.O., 1980, "Dielectric Healing of Mixtures Containing Coal and Pyrite," J. of Microwave Power, Vol. 15, No. 3, pp. 187-190.

Hotta, M., Hayashi, M. and Nagata, K., 2011, "High Temperature Measurement of Complex Permittivity and Permeability of $\mathrm{Fe}_{3} \mathrm{O}_{4}$ Powders in the Frequency Range of 0.2 to $13.5 \mathrm{GHz}$," ISIJ International, Vol. 51, No. 3, pp. 491-497.

Jensen, E., 1942, "Pyrrhotite; Melting Relations and Composition," American Journal of Science, Vol. 240, pp. 695-709.

Lee, S.J., Shin, H.Y., Bae, I.K. and Chae, S.C., 2008, "Report on Upgrading Technology for Low-Rank Coal," $J$. of the Korean Society of Mineral and Energy Resources Engineers, Vol. 45, No. 3, pp. 276-282.

Liu, K., Schmedake, T.A. and Tsu, R., 2008, "A comparative study of colloidal silica spheres: photonic crystals versus Bragg's law," Physics Letters A, Vol. 372, Issue. 24, pp. 4517-4520.

Nelson, S.O., Beck-Monthomery, S.R., Fanslow, G.E. and Bluhm, D.D., 1981, "Frequency Dependence of the Dielectric Properties of Coal - Part II," J. of Microwave Power and Electromagnetic Energy, Vol. 16, Issue. 3, pp. 319-326. Okolo, B., Lamparter, P., Welzelv, U. and Mittemeijer, E.J., 2004, "Stress, texture, and microstructure in niobium thin films sputter deposited onto amorphous substrates," J. of Applied Physics, Vol. 95, Issue. 2, pp. 466-476.

Peng, Z., Hwang, J.Y., Mouris, J., Hutcheon, R. and Huang, X., 2010, "Microwave Penetration Depth in Materials with Non-Zero Magnetic Susceptibility," ISIJ International, Vol. 50, No. 11, pp. 1590-1596.

Peng, Z., Hwang, J.Y., Mouris, J., Hutcheon, R. and Sun, X., 2011, "Microwave Absorption Characteristics of Conventionally Heated Nonstoichiometric Ferrous Oxide," Metallurgical and Materials Transactions A, Vol. 42, No. 8, pp. 2259-2263. 
Pickles, C.A., Mouris, J. and Hutcheon, R., 2005, "Hightemperature Dielectric Properties of Goethite from 400 to 3000 MHz," J. of Materials Research, Vol. 20, No. 1, pp. $18-29$.

Toulmin, P. and Barton, P.B., 1964, "A Thermodynamic Study of Pyrite and Pyrrhotite," Geochimica et Cosmochimica Acta, Vol. 28, Issue. 5, pp. 641-671.

Uslu, T. and Atalay, U., 2004, "Microwave heating of coal for enhanced magnetic removal of pyrite," Fuel Processing
Technology, Vol. 85, pp. 21-29.

Weng, S., 1993, "Mössbauer Analysis of the Microwave Desulfurization Process of Raw Coal," J. of Applied Physics, Vol. 73, Issue. 9, pp. 4680-4682.

Weng, S., Wang, J., Wang, Z., Yan, J., Wu, Z., Lin, D., YU, Y. and Zhao, C., 1990, "Mössbauer Study of the Microwave/magnetic Desulfurization of Yutianbao Coal," Hyperfine Interactions, Vol. 58, Issue. 1-4, pp. 26292633.

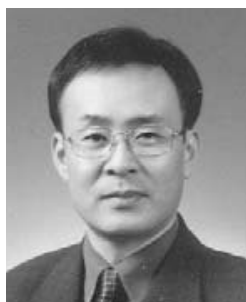

\section{김 병 곤}

1994년 연세대학교 대학원 세라믹공학 과, 공학석사

2000 년 강원대학교 대학원 자원공학과, 공학박사

현재 한국지질자원연구원 광물자원연구본부 책임연구원, 과학기 술연합대학원대학교 자원순환공학과 교수

(E-mail; bgkim@kigam.re.kr)

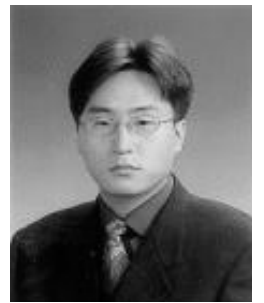

\section{박 종 력}

2002년 강원대학교 대학원 지구시스템 공학과, 공학석사

2009년 강원대학교 대학원 지구시스템 공학과, 공학박사
현재 포스코기술연구원 원료연구그룹 책임연구원 (E-mail; clpark@posco.com)

\section{이 재 령}

현재 강원대학교 에너지자원공학과 부교수 (本 學會誌 第49券 第6号 參照) 